cenzorskiego ołówka Stuibera.

Spośród wielu publikacji jubileuszowych, o których niniejszy zeszyt na innym miejscu wyczerpująco informuje, ta jest bez wątpienia najwazntejsza, bo o św. Benedykcie nie tylko mówi, ale przede wszystkim on sam $z$ nief przemawia. Na razie mprawdzle tylko do "piskląt Bożych" 1 , bo książka nie była w obiegu księgarskim, ale mamy niepłonną nadzieję, ze następne jej, uzupełnione, wydanie ukaże się równiez pro foro externo.

\title{
Andrzej Bober SJ
}

\section{O REGULE SWIETEGO BENEDYKTA BEZ BENEDYKTYNSKIEJ POKORY}

Ernst Friedrich Sauer, Benediktsregel' und Weltleute, Augustin = Hangelar 1980, stron 273 , format $8^{\circ}$

Czytelnik pragnący zapoznać się z najnowszymi pracami o Regule św. Benedykta, znajdzie zapewne w katalogu bibliotecznym m.in. wyżej wymienioną pozycję. Jeśli idąc w ślad za owa informacją sięgnie po nią w nadziei, ze dotarł do obszernej monografii, to na pierwszy rzut oka nie zauwazy nawet, ze stał się

1 Przyjaciel Polski i męczennik św. Brunon z Kwerfurtu /+1009/ tak opisuje w 1004 r. pielgrzymkę św. Wojciecha do relikwii św. Benedykta: "Pomknął Wojciech do ogromnego klasztoru we Fleury, gdzie leży pochowany i cudami jaśniejący nauczyciel tych, co światu umierają i całym sercem tęskniaz za niebem, mianowicie i z imienta, i rzeczywistości błogosławiony Benedykt, winem i oliwą świetnie leczący chorych, sławna po całym świecie matka piskląt Bożych, tulących się w oieniu jego skrzydeł"/Pı́́miennictwo czasów Bolesława Chrobrego, jw. s.127/. 
ofiara swoistego rodzaju dezinformacji. Winy za to bynajmniej nie ponosi bibliotekarz opracowujący kartę katalogową, głównie w oparciu o stronę tytułową $i$ końcowa książi. Imiona 1 nazwisko autora umieszczone grubą czcionką po raz pierwszy u góry na okładce, po raz drugi na tzw. "koszulce", po raz trzeci na karcie tytulowej 1 po raz czwarty na grzbiecte ksiazki - sugeruja wyraźnie, ze mamy do czynienia z jakąś powaźną rozprawą lub obszernym studium na temat relacji Reguky św. Benedykta do ludzi świeckich, na co wskazywałaby dość pokaźna llość stron - 273, /taką bowiem liczbę nosi ostatnia zadrukowana strona ksiązki/ oraz problemowe sformulowanie tytuku:"Reguła Benedyktyńska a ludzie świeccy". Apetyty czytelnicze dodatkowo zaostrza umieszczona na tylnej okładce ksiązki reklamómka informująca, ze "Ksiązka ta spotkała sie z ostra krytyka juz przed swoim drukiem, z racji tej, ze krytykuje klasztory, które, zwłaszcza jeśli chodzi o ich przełożonych, nie chca zazwyczaj byé krytykowane". Jej autor kreuje się wręcz na wielkiego reformatora, który będąc, z racji przeprowadzonych studiów, upowaznionym jakoby do podawania projektów naprawy zycia zakonnego, juź na początku spotyka się z niechęcia 1 brakiem zrozumienta. Jak wezwanie do krucjaty brzmia słowa: "Od nas to - ludzi śwleckich i zakonników - zalezy 1 waszej to jest mozliwośc1, by Reguła benedyktyńska zyskała nowy kształt 1 zapanowała wszędzio jako pokojowy porządek, tak w klasztorach jak i poza nimi, dziś w tych ciezkich, pełnych chaosu 1 gwaltu czasach".

Po tak wspaniakych zapowiedziach czytelnik oblecujacy sobie interesująca lekturę, jakze srodze zostante zawiedziony po przystąpieniu do szczegółowego studium.

Praca E.F. Sauera sklada sie bowiem z dwustronicowej przedmowy, dwustronicowego zyciorysu sw. Benedykta, odbitki kserograPicznej/75 stron/ tekstu Reguly św. Benedykta, wydanej czcionka 
gotycką w 1911 roku w Pradze, uwag 1 refleksjl autora do poszczególnych rozdziałów Reguły /77 stron/ oraz indeksów /4 strony/. Jak latwo obliczyć w sumie cała praca składa się ze 160 stron tekstu, w tym zaledwie 81 stron napisanych przez autora. Skąd więc wzięła się paginacja "273"? Gdyby ktoś poprzestał na przestudiowaniu spisu treści umieszczonego na stronie ósmej, nie zdołałby odpowsedzieć na to pytanie. Pozycja pierwsza, tj. Przedmowa, znajduje się na stronie 9, życiorys sw. Benedykta na stronie 11, tekst Reguly na stronie 88. Logicznie rzecz biorąc nalezałoby oczekiwać, ze na stronach 11-88, czyli 77 stronach znyjduje się życiorys św: Benedykta. Nio podobnegol źyciorys liczy sobie tylko 2 strony, tj. mieści się na stronie 111 12, z tym ze strona 12 oznaczona jest następująco: "12-87". W ten sposób strona 13 nie jest trzynastą, lecz juz 88 . Inaczej mówiąc strony $13,14,15$ itd. aź do 86 w tekście w ogóle nie istnietą.

Strona 13, w tekście liczona jako 88, jest odbitka kserograficzną karty tytułowej: "Leben und Regel des heiligen Paters Benediktus. Mit 75 Illustrationen. Prag 1911", Autor opuślł strony od 1 do 88, na których by obszerny zyciorys śm. Benedykta i przeszedł od razu do tekstu Reguły, tj. do strony 89, chcąc zachować zastaną tam paginacje. Tekst Reguły obejmuje strony 89-191. Gdyby ktoś sądził, że w sumie na 102 stronach zawiera sie tekst Reguły, bardzo by sie pomyliz. Z 75 ilustracji zamieszczonych w tekście oryginalnym E.F. Sauer opuśc1ł az 57, stąd tez wypadły niektóre strony, w tekście zaś powstały takie paginacje, jak: "92-94", "96-98", "104-106", "110-114", "118-120", "128-132", "136-138", "140-142", "148-150", "160162", "166-168", "172-174". W sumie autor "połknąz" następnych 27 stron, co w połaczeniu z poprzednimi 75 stronami daje razem 102 rikcyjne strony. Cała książka zatem nie liczy 273 strony, 
ale, po dodaniu nawet spisu treści, kart tytułowych oraz indeksów, tylko 171 stron. Mamy tu do czynienia z zamierzoną lub niezamierzoną dezinformacją co do objętości pracy.

Dalsza dezinformaoja dotyczy charakteru naukowego omamianej pozycji. Okładka i strona tytułowa zapowiadaja monografie problemowa. W rzeczywistości to, co autor od siebie oryginalnego daje, to 77 stron uwag 1 refleksji, które nazwał "komentarzem". Tu jednak ponownie budzą s1ę wątpliwości, czy można to nazwać komentarzem? W Przedmorie sam przyznaje, ze tego nie można nazwać komentarzem naukowym /s.10: "Natürlich immer im Rahmen dieser wenigen Seiten, die man Preilich keinen wissenschaftlichen Kommentar nennen daren/. Dodaje przy tym, ze istnieją róznego rodzaju komentarze 1 sugeruje, lź jego praca jest rodzajem komentarza popularno-naukowego. Co do tego zdaje sie nie mieć wątpliwości, bo na całej stronie 192 umieścił tłustym drukiem, duzymi literami tytuł: "Kommentar".

W Przedmowie przytacza równoczé́nie opinię tych /nie podaje nazwisk/, którzy czytali jego pracę waszynopisie i orzekl1, źe moźna ja nazwać nieusystematyzowanym felietonem, a nie komentarzem /s.10:"Schliesslich hat man gesagt, ich hllte überhaupt keinen Kommentar geschriben, sondern ein unsystematisches Feuilleton"/. Odwołuje się przy tym do sądu czytelnika, by ten rozstrzygnął, jak krzywdząca jest ta opinia. Niestety, wszystko wskazuje, ze owi pierwsi czytelnicy pracy Sauera wydali słuszny osąd. Jeśli nawet autor zamierzal komentować Regułe św. Benedykta pod kątem aktualności w dzisiejszych czasach, szczególnie w odniesieniu do ludzi świeckich, nie trzymał sie konsekwentnie tego wątku tematyoznego, lecz zamieścił repleksje i uwagi, jakie tylko w danej chwili clsnęły mu się pod pióro. Najogólniej mozna by mówié o czterech wątkach tematycznych: 1/ krytyce zycia współczesnych klasztorów, 
2/ nieaktualności przepisów Reguły św. Benedykta,

3/ Regule św. Benedykta a ludziach świeckich,

4/ uwagach kaznodziejsko-moralizatorskich.

Jeśli chodzi o krytykę życia współczesnych klasztorów, są to uwagi dosyć powierzchowne. Autor wymawia np. opatom $i$ przełozonym ich skłonności do odbywania licznych podrózy /s.197,207/, przypomina im obowiązek dawania dobrego przykładu /s.198,208/. Zakonnikom i zakonnicom wypomina "trwające często w klasztorach długoletnie spory 1 kłótnie, gdzie bracia i siostry nie pozdrawiaja sie, nie rozmawiaja ze sobą, a nawet potajemnie przeciw sobie agituja" /s.202-203/ oraz noszenie "fantastycznych ubiorów" /s.251/. W sumie tymi uwagami nic nie wnosi do problematyki zapowiedzianej w tytule pracy.

Drugi wątek tematyczny powracający dosyć często na kartach "komentarza" to wskazywanie na nieaktualność 1 przestarzałość przepisów Reguły św. Benedykta. I znowu powstaje nieporozumienie: przeciez autor deklaruje na wstępie, ze będzie eksponował to, co w niej jest stale aktualne i potrzebne współczesnemu człowiekowi świeckiemu. Twierdzi nawet, ze "Reguła ta dla człowieka świeckiego może stać się nie tylko eliksirem życia, lecz także czymś w rodzaju vademecum, przy pomocy którego będzie potrafił, jeśli tylko zechce, odpowiedzleć sobie na wiele kwestii, jakie niesie ze sobą życie codzienne"/s.193/. Po co więc autor zajmuje sie roztrząsaniami na temat tego, ze urząd opata nie powinien być dożywotni/s.199/, ze w czasach dzisiejszych absolutny autorytet opata jest nie do przyjęcia, bo "gdyby maź Bozy przewidzial dzisiejsze czasy, wydałby zapewne inny przepis" /s.245/; po co uwaga przy rozdziale 51 i 54, ze przepisy $1 \mathrm{ch}$ sa przesadzone /s.245 \& 250/. Nie moźna zakwestionować słuszności tych uwag. Nie wnoszą one jednak niczego do głównej problematyki pracy. 
Jeśli juz nawet autor zajmuje slę relacją Reguły do ludzi świeckich, to nie na zasadzie analizy rzeczowej danego przepisu, lecz na zasadzie hasła wywoławczego określonego tematu. Np. rozdział $V$ "O posłuszeństwie" wywołuje lawinę uwag 1 refleksji o posłuszeństwie w ogóle, rozdział VI - o milczeniu, VII - o pokorze itd. Nie potrzeba az Reguły św. Benedykta, zeby na te tematy coś powiedzieć. $Z$ drugiej strony nie nalezy zapominać, ze Reguła ta posiada martosć uniwersalna i ponadczasowa z racji swego źródłowego oparcia na tekstach Pisma Swiętego. Stąd niektóre jej przepisy były, są 1 będą zawsze aktualne, Jak stale aktualne jest Pismo Swięte. Równie dobrze mógłby autor podać swoje refleksje o milości bliźniego i modlitwie na kanwie przepisów Reguły św. Augustyna, Reguły św. Pachomiusza czy Reguły św. Bazylego, które są, obok Pisma św., podstawowymi źródłami do Reguły św. Benedykta. Autor za słabo uwzględnia specyfike 1 oryginalnośc ducha Reguly benedyktyńskiej.

Czwarty wątek tematyczny w "komentarzu" Sauera - uwagi kaznodziejsko-moralizatorskie - sa często po prostu zwykłymi truizmami. Czy az trzeba było czwartego rozdziału Reguły św. Benedykta, by stwierdzić, ze "tak zakonnik, jak i świecki, nie powinien codziennie długimi godzinami wysiadywać przed telewizorem"/s.205/ oraz ze "istnieje czystość małzeńska", a "mnich winien zachowywá́ doskonałą czystośc, człowiek zonaty zaś czystość małzeńską" /s.207/, albo rozdziału 63, by dowiedzieć się, ze "młodzi ludzie winni czcić starszych, starsi zaś kochać młodych" /s.258/.

Przy tym wszystkim autor jest zbyt subiektywny. Często jego wasne zdanie, czy po prostu wasne "widzi mi się", ma zastapic ozytelntkowi rzeczowe argumenty 1 logiczne racje. Zwroty typu: "jestem tego zdania", "ja tak sądzę", "tak mi się wydaje" powtarzają się dosyó często /s.215: "So jedenfalls die tberse- 
tzung von Luther, die mir gut gefll1t"; s. 216: "Ich selber fand das in den Klöstern des Athos"; s. 264: "Diese Vorschrift ist mir persönlich immer als etwas unangebracht vorgekommen"; s. 245: "Ich bin daher der Meinung"; podobnie na stronach: 251, 253,254/. Czytelnik ma prawo oczekiwać obiektywnego wyjaśnienia. Mało go obchodzá poglądy autora na wiele spraw. Subiektywizm Sauera sprawia, ze to co napisał nie moźna "komentarzem", ile raczej "osobistymi odczuciami i refleksjami" nad Regułą św. Benedykta. Nie przesądza to faktu, ze autor nie ma racji, wrecz przeciwnie, w wiekszości saz to słuszne sądy i opinie. Autor jest erudyta. Powołuje się na Arystotelesa, Tomasza z Akwinu, Heidegera, Martaina, Eckhardta. Z zamieszczonej na końcu ksiązki bibliografii jego prac oraz z uwag zamieszczonych w Przedmowie, dowiadujemy się, że autor grównie zajmuje się filozofia. Często odwołuje sie do komentarzy naukowych do Reguły św. Benedykta, w szczególności do komentarza C.Butlera, opata z Downside: Benedictine Monachism, London $1924^{2}$ /cytuje przekład niemiecki: Benediktinisches Mőnchtum, St.ottilien 1929/ oraz do siedmiotomowego komentarza Adalberta de Vogllé, La Règle de St. Benô̂t, Paris 1972-1977/. W tym wszystkim jednak daje sie zauważć sporo dyletantyzmu i chęci popisania się erudycją. Na zwykła fanfaronadę zakrawa ciągłe cytowanie upatrzonych zwrotów Reguły w języku niemieckim, angielskim, francuskim i holenderskim/szkoda, ze pominął chínski i arabski/. Po co? Chyba po to, by czytelnikowi uświadomić, ze jest poliglotą. Orszem, miałoby to sens przy komentarzu filologicznym, gdzie konieczne sa analizy semantyczne, poniewaź każdy przekład zawiera swoistego rodzaju interpretacje. Wówczas jednak nalezałoby szeroko uwzględnić łaciński tekst oryginalny Reguły, czego autor dostatecznie nie czyni. Gdyby któs chciał za wszelkaz cenę bronić Sauera, to być moze udałoby mu sie udowodnic, ze np. na stronie 216 podanie tych 
przekładów rzuca jakieś nowe światło. Być moze. W zasadzie jednak jest to zupełnie zbędne $i$ nic istotnego nie wnosi do meritum sprawy.

Dla ścisłości naleźy teź dodać, ze autor nie pisze uwag do wszystkich 73 rozdziałów Reguły. Lączny "komentarz" pisze do rozdziałów 9-20, oraz 23-28. W pierwszyn wypadku na 2 strony, w drugim na 3 strony. Rozdziały 32,47 i 50 pozostawia bez komentarzy; przy rozdziale 54 zamiescił uwagę: "Ten przepis jest przesadzony". W sumie pominąz 21 rozdziałów, co stanowi 29\%. Niektóre rozdziały maja komentarze kilkuwierszowe/rozdz.35 - 9 wierszy; rozdz.45 - 8 wierszy; rozdz.60 - 6 wierszy/, inne zaś kilkustronicowe/Prolog - 2,5 strony; rozdz.2 - 4 strony 11 wierszy; rozdz.4 - 3 strony i 27 wierszy/.

Powstaja dwa zasadnicze pytania: pierwsze, czy w og6le było warto ogłaszać drukiem jego pracę, drugie, czy autor miał prawo w tej formie ją publikować. Odpowiadając na pierwsze należy jasno stwierdzić, ze mamy tu do czynienia nie z rozprawa naukowa lecz ze zbiorem notatek, luźnych uwag i refleksji. Sa to materialy do homilii czy medytacji, ewentualnie do jakiegoś artykułu popularno-naukowego. Celowośc publikowania tych materiałów nalezy uznać za chybioną. Autor wykazuje kompletny brak zmysłu syntezy. Załózmy, ze nie będac w stanie napisać pracy syntetycznej, uznal za waściwe opublikowanie swyoh spostrzezeń. W tym wypadku jednak forma, waklej to uczynił, śviadczy o zawyzonych aspiracjach. Jego publikacja jest typowym przykładem tzw. pracy "dobrze sprzedanej", Jednak bez benedyktyńskiej pokory 1 uczoiwośoi, która sam tak się zachwyca. Formalnie autor powiekszył swój dorobek o jedną pozycję ksiązkowa więcej, de facto sprzedał towar dosyé mierny w bardzo efektownym opakowaniu. Czytelnik czuje sie rozczarowany 1 oszukany, jak kazdy, komu towar czwartego gatunku aprzedaje sie za pierwszy. To, co napisaz E.F.Sauer, 
posiada jakąś wartość. Błąd w tym, ze będąc wróblem udaje sokoła. Szkoda, mógłby tego uniknąć, gdyby zaczął od nauki benedyktyrískiej pokory, a nie od pisania o niej.

ks. Franoiszek Drączkowsk1

4. ALBUM 0 STIETYM BENEDYKCIE

Walter Nigg, Benedikt von Nursia. Der Vater des abendlandischen Monchtums. Mit 50 Farbbildern von Helmuth Nils Loose. Freiburg 1979 , Herder, s.116.

Nie jest to pozycja naukowa, ale książka-album, przygotowana z okazji 1500-lecia urodzin św. Benedykta, w celu przypomnienia i zainteresowania współczesnego czytelnika postacia 0jca monastycyzmu zachodniego. Może się to wydawać dziwne, ze jej autor będąc protestantem, pastorem i profesorem historii Kościoła na Wydziale Teologii Kalwińskiej w Zurychu, uchodzi dziś za jednego z najwybitniejszych wspołczesnych hagiografów. Swiętych - wybitnych bohaterów chrześcijaństwa - charakteryzuje Nigg w sposób budzący zainteresowanie, w oparciu o źródła, lecz językiem dziennikarsko-reporterskim, najczęściej połączeniu z jakimś albumem. Spod jego pióra wyszły m.in. biografie, Jak: Der Mann aus Assisi, - Franciskus und seine Welt /Freiburg 1976, tłum. na jæzzyk polski 0.Kajetan Ambrozkiewicz, w: J.Lortz, W.Nigg, Swiety z Asyżu, Warszawa 1979, S.71-109/; Thomas Morus - Heilige des Gewissens /Fre1burg 1977/; Martin von Tours - Leben und Bedeutung des wundertatigen Bischofs und mutigen Bekenners/Freiburg 1978/; Elisabeth 